\title{
Correction to: Cultural Change Reduces Gender Differences in Mobility and Spatial Ability among Seminomadic Pastoralist-Forager Children in Northern Namibia
}

\author{
Helen E. Davis ${ }^{1}$ (D) Jonathan Stack ${ }^{2}$ - Elizabeth Cashdan ${ }^{3}$
}

Published online: 14 May 2021

(c) Springer Science+Business Media, LLC, part of Springer Nature 2021

\section{Correction to: Human Nature https://doi.org/10.1007/s12110-021-09388-7}

In the text under the heading "Effects of Environment and Spatial Experience on Spatial Skills," the authors would like to make the following correction:

(as published): Berry (1966), similarly, noted excellent spatial abilities in a population of Alaskan Native women and men.

Correction: Berry (1966), similarly, noted excellent spatial abilities in a population of Nunavut Inuit women and men.

Publisher's Note Springer Nature remains neutral with regard to jurisdictional claims in published maps and institutional affiliations.

The original article can be found online at https://doi.org/10.1007/s12110-021-09388-7.

Helen E. Davis

helenelizabethdavis@gmail.com

1 Department of Human Evolutionary Biology, Harvard University, Cambridge, MA, USA

2 One Pencil Project, 501(c)(3), Salt Lake City, UT, USA

3 Department of Anthropology, University of Utah, Salt Lake City, UT 84112, USA 